\title{
アルミナにおける成形体及び焼結体特性に及ぼす原料調製条件の影響
}

\author{
杉浦勇夫・野村 浩・篠原伸広*・椿 淳一郎 \\ (財)ファインセラミックスセンター，456 名古屋市熱田区六野 2-4-1 \\ *旭硝子(株)中央研究所, 221 横浜市神奈川区羽沢町 1150
}

\section{Effect of Preparation Conditions on Properties of Green and Sintered Body in Alumina} Isao SUGIURA, Hiroshi NOMURA, Nobuhiro SHINOHARA* and Jun-ichiro TSUBAKI

Japan Fine Ceramics Center, 2-4-1, Mutsuno, Atsuta-ku, Nagoya-shi 456

*Research Center, Asahi Glass Co., Ltd., 1150, Hazawa-cho, Kanagawa-ku, Yokohama-shi

221

The effect of preparation conditions of alumina ceramics to the properties of green and sintered bodies was investigated. In this experiment, both ball milling and attrition milling techniques were applied to prepare the suspensions, and the effects of the content of an organic binder, the temperature of spray drying, and the pressure of uniaxial mold pressing and CIPing were studied to the properties of green and sintered samples. Results indicated that the density and the pore size distribution of the green compact depended upon the content of a binder, showing the densities of compacts before dewaxing were higher in the case of more amount of an added binder probably due to the effects of improved plasticity and lubricity of granules. After dewaxing, however, the addition of lower amount of a binder contributed to the increase of green densities with the formation of small pores in the matrix. Decrease of an added binder was also effective to obtain the increased density and the improved bending strength after sintering.

Key-words : Alumina, Binder, Ball mill, Attrition mill, Green density, Sintered body, Bending strength

\section{1. 緒 言}

構造用ファインセラミックスが，ユーザーから信頼を得 て広く使用されるためには，特性上の欠点である脆さを克 服することと製造コストの低減が必要である。セラミック ス製品の多くはそのコストの半分近くが加工コストであ り，この加工コスト低減のための研究開発が各方面で進め られている。しかし研究者が使用するファインセラミック 又試験片の多くは，その素性が明らかでなかったり特性が まちまちであるため，貴重な研究データを相互比較できな いのが現状である。

以上のようなことから，ファインセラミックスの加工に 関する工作機械や工具などの統一的性能評価ができるよう な，標準的なファインセラミックス試料を供給することが 必要でめると考えられ，はじめに使用量の多いアルミナ焼 結体の開発を行った。

これまで，アルミナ焼結体の製造研究について，特に焼 結助剂添加量及び焼結条件が焼結体の特性や微構造に与え る影響1)について検討を進めてきた。本報では原料調製条
件，特にバインダ一配合量が成形体及び焼結体特性に与え る影響について考察を行った。これまでバインダーの特性 と成形性については，バインダーのゲル化特性を利用した 顆粒の調製 2 や，成形時におけるバインダ一強度に与える 湿度の効果 ${ }^{3), 4)}$, あるいはバインダーのガラス転移温度と 成形性 ${ }^{5), 6)}$ ，また成形体の圧密構造が焼結体に与える影

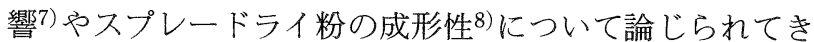
た。しかしプレス成形においてバインダーの配合量や原料 調製時の条件が成形性や，特に焼結体の特性にどのような 影響を与えるかについてはあまり明らかにされていない。

本報告では，第一にバインダー配合量が成形圧の変化に 伴い成形体密度や成形体の累積細孔容積にどのような影響 を与え，その結果として焼結体密度がどのように変化して いくのかを考察し，第二に媒体かくはんミルを使用したと きの原料調製条件が最終的に焼結体の密度や強度に与える 影響について検討した。

\section{2. 実験方法}

\section{1 アルミナ焼結体の基本的製造プロセス}

本実験のプロセスを図 1 に示す，原料のアルミナは，純 度99.8 wt\%で平均粒径0.4 $\mu \mathrm{m}$ の住友化学工業製の低ソー ダ易焼結性アルミナである. 原料には焼結助剤としてマグ ネシアが $0.1 \mathrm{wt} \%$ 添加されている. 粉砕方法はボールミル と量産を念頭に置いた媒体かくはんミルの 2 種類である. この 2 種類の方法で粉砕処理されたスラリーにバイン ダーを所定量加えかくはん混合する。

バインダー混合後のスラリーをスプレードライヤーで乾 燥, 造粒し, 顆粒を金型及び CIP 成形した。成形体は室 温から $500^{\circ} \mathrm{C}$ まで 15 時間で昇温し, $500^{\circ} \mathrm{C}$ で 2 時間保持し て脱脂を行った。焼成は $1600^{\circ} \mathrm{C}$, 保持時間 2 時間で行い, 焼結体の密度はアルキメデス法により測定した。 また曲げ 強度は室温の 4 点曲げ強度で JIS R1601に従い測定した。

\section{2 ボールミルによる原料調製実験}

原料の調製は $5 l$ のポリエチレンポットに原料, 解膠 剤, 蒸留水を加え直径 $2 \mathrm{~mm}$ のアルミナボールで 24 時間 混合した. スラリーの配合割合は表 1 に示す. バインダー の配合量は固形分換算で原料に対して $1.5,3.0,6.0 \mathrm{wt} \%$ で ある. 混合後のスラリーにワックス系バインダー（中京油 


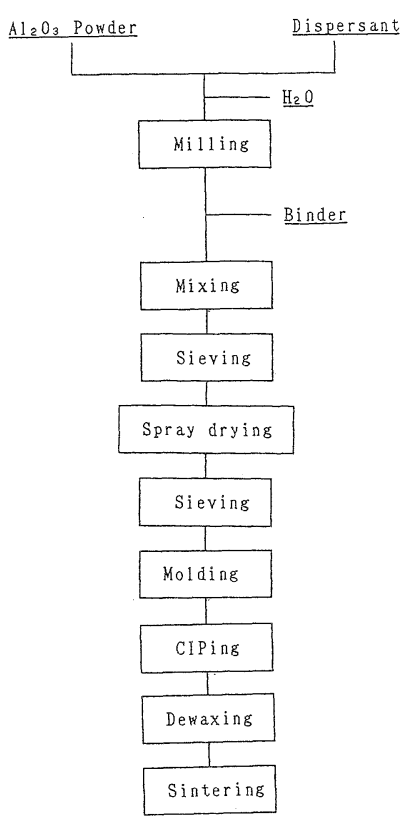

Fig. 1. Fabrication process of $\mathrm{Al}_{2} \mathrm{O}_{3}$ body.

Table 1. Composition of $\mathrm{Al}_{2} \mathrm{O}_{3}$ slurries with various binder contents.

\begin{tabular}{c|c|c|c}
$\mathrm{Al}_{2} \mathrm{O}_{3}$ Powder $(\mathrm{g})$ & Water $(\mathrm{g})$ & Dispersant $(\mathrm{g})$ & $\begin{array}{c}\text { Binder as solid } \\
\text { (wt\% added to powder) }\end{array}$ \\
\hline 2000 & 900 & 10 & 1.5 \\
\hline 2000 & 900 & 10 & 3.0 \\
\hline 2000 & 900 & 10 & 6.0 \\
\hline
\end{tabular}

脂製，セルナWD830）を所定量加え，かくはん混合しス プレードライヤーで造粒した．顆粒はその大きさと形状を 光学顕微鏡で観察し, 更にタップ密度を測定した. 30〜 $120 \mathrm{MPa}$ の圧力で金型成形した成形体の寸法は直径20 $\mathrm{mm}$ 厚さ約 $12 \mathrm{~mm}$ である。 その後成形体を 150 ～300 $\mathrm{MPa}$ の圧力で CIP 処理した. この成形体のバインダーを 含んだ脱脂前と，バインダーを分解処理した脱脂後の密度 を寸法, 重量から求め, 水銀ポロシメータによる細孔径分 布の測定を行った。

\section{3 媒体かくはんミルによる原料調製実験}

媒体かくはんミル（アシザワ製，PM5RL-V）は, 粉砕 部のベッセル，シャフト及びディスクがウレタンでライニ ングしてある.粉碎には直径 $2 \mathrm{~mm}$ のアルミナボールを 使用した。 スラリーの粉砕混合時間は30分と 330 分とし た。バインダーの配合量については, 2.1節のボールミル 粉砕実験の結果を参考にして, 少量のバインダー配合によ る実験を行うこととし，原料に対して $0.5 \mathrm{wt} \%$ と $1.5 \mathrm{wt} \%$ の配合割合とした。また顆粒の製造条件は熱風入口温度を $120^{\circ} \mathrm{C}$ と $170^{\circ} \mathrm{C}$ の 2 水準とした. 成形は $20 \mathrm{MPa}$ の圧力で金 型成形した。成形体の寸法は直径 $20 \mathrm{~mm}$ 厚さ約 $12 \mathrm{~mm}$ と, 曲げ強度測定用の $50 \times 60 \times$ 約 $5 \mathrm{~mm}$ である. 金型成 形後, 成形体を150 200 MPa の圧力で CIP 処理した.

\section{3. 実験結果及び考察}

\section{1 ボールミルで調製した原料を用いた場合の成形体, 焼結体の性質}

図 2 に顆粒のタップ密度とバインダー配合量の関係を示 してある. タップ密度はバインダーの配合量が多くなるに 従って小さくなることを示している.な扔, 顆粒の光学顕 微鏡の観察結果において, バインダーの配合量の違いによ る顆粒の寸法, 形状の差は特に認められなかった。

図 3 は脱脂前と脱脂後の成形体相対密度と成形圧力の関 係を示しており，脱脂前の成形体は成形圧が高くなるに 従って, 成形体相対密度はバインダー配合量の多い方が高 い值を示している.しかし，脱脂後の成形体はバインダー の少ない方が成形圧に関係なく, 成形体相対密度は同じか やや高くなっていることが分かる.

図 4 及び図 5 には水銀ポロシメータによる細孔分布測定 結果を示してある. 図 4 は脱脂前の CIP 圧が $300 \mathrm{MPa}$ に 抢ける累積細孔容積と細孔径の関係を示してあり,バイン ダー配合量の多い方が累積細孔容積は小さいことを示して いる. また図 5 の脱脂後の CIP 圧 $300 \mathrm{MPa}$ ではバイン ダ一配合量の少ない方がやや小さい累積細孔容積を示して いる.つまり, 成形体に圧力が加わることによりバインダー の配合の多い方が可塑性, 潤滑性の効果がより強く発揮さ れ充填性はよくなり, 累積細孔容積は小さく, 結果として 密度は高くなる. しかし脱脂後はバインダーが抜け, 図

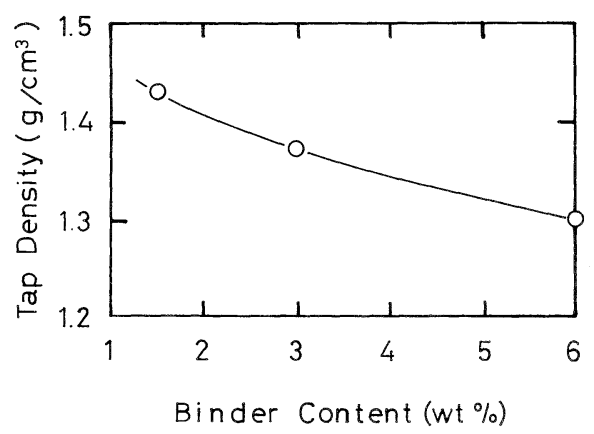

Fig. 2. The relation between tap density and binder content of granules.

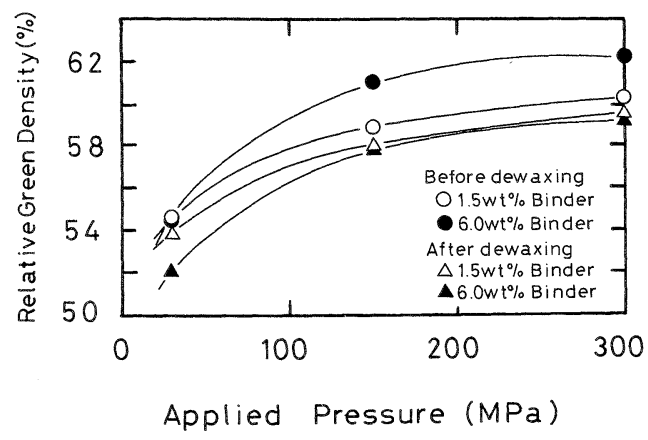

Fig. 3. The relation between relative green density and applied pressure on the before and after dewaxing compacts. 


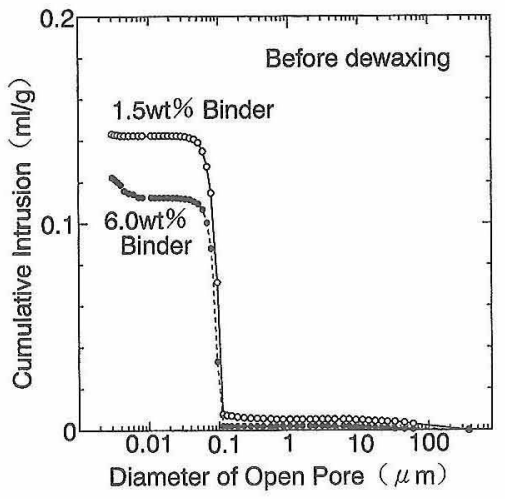

Fig. 4. Pore distribution of compact before dewaxing, which was compacted under $300 \mathrm{MPa}$.

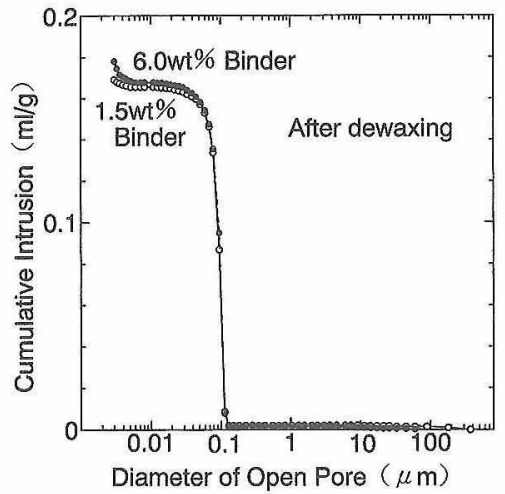

Fig. 5. Pore distribution of compact after dewaxing, which was compacted under $300 \mathrm{MPa}$.

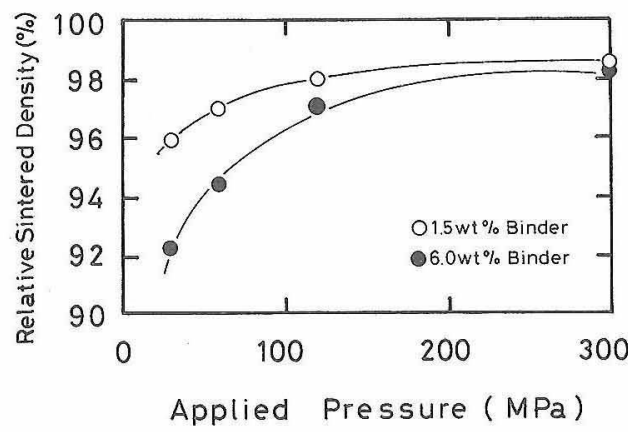

Fig. 6. The relation between relative sintered density and applied pressure.

5 のように累積細孔容積はバインダー配合量の少ない方が やや小さい結果を示した．この結果は図 3 の脱脂前後の 成形体相対密度と成形王力の結果に対応している。

図 6 は焼結体相対密度と成形圧の関係を，バインダー配 合量が1.5 wt\%と6.0 wt\%について示したものである.成 形圧が低圧側では，バインダー配合量の少ない方が燒結体 密度は高い值を示し，成形王が高くなるに従ってその傾向 は小さくなっていくが，成形圧が300 MPaになっても図 6 の結果はバインダーの少ない方が依然としてその密度は 高く, 図 3 の脱脂後の成形体密度と成形圧力の関係とほ ぼ同じ傾向を示している。
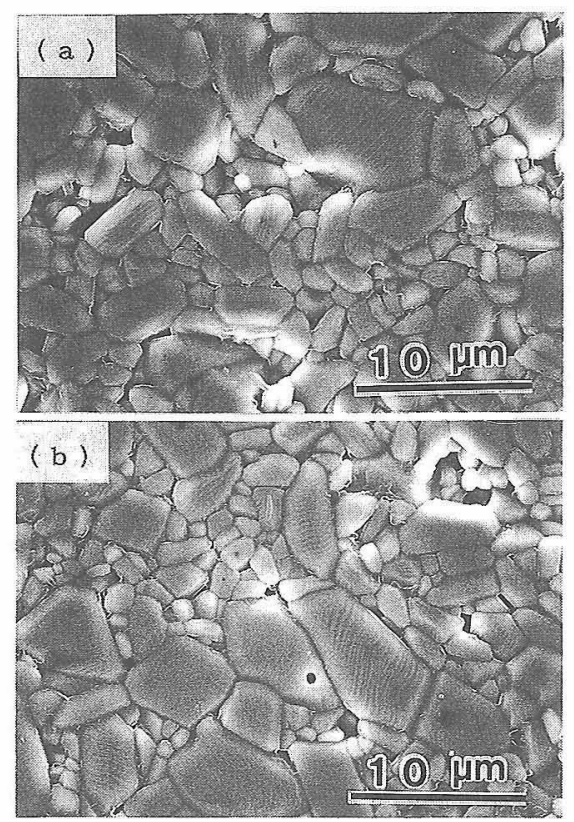

Fig. 7. SEM photographs of thermal etched surface of compact with 1.5 wt\% binder (a) and with $6.0 \mathrm{wt} \%$ binder (b).

図 7 (a),(b)にバインダー配合量が1.5 wt \% と 6 wt\%の 走査型電子顕微鏡 $(\mathrm{SEM})$ 写真（熱エッチング面）を示 す。図 7 からバインダー配合量による組織の差はほとん ど認められなかった。

\section{2 媒体かくはんミルで調製した原料を用いた場合の 成形体，焼結体の性質}

原料の粒度分布は原料が易焼結性のアルミナでもともと 粉碎が十分されていたということもあり，粉碚前後とも粒 度分布の差はほとんどなかった。

スプレードライヤーによる顆粒の製造は 2 種類の温度 で行ったが，外見上は顆粒の形状や寸法にほとんど差は認 められなかった。衰 2 はこれら顆粒の相対タップ密度をバ インダー配合量に対して示したものである. バインダー配 合量の少ない方が密度は高い值を示し，こ机はすべての条 件（粉砕時間，スプレー温度）にかかわらず同じ傾向を示 した。

Table 2. Relative tap density (\%) of granulated powders with various preparation conditions.

\begin{tabular}{|c|c|c|c|}
\hline \multirow{2}{*}{\multicolumn{2}{|c|}{ Preparation conditions }} & \multicolumn{2}{|c|}{ Binder content } \\
\hline & & $0.5 \mathrm{wts}$ & 1. 5 wix \\
\hline \multirow{2}{*}{$\begin{array}{l}\text { Mllling time } \\
=30 \text { min. }\end{array}$} & $\begin{array}{l}\text { Spray drying } \\
\text { temp. }=120^{\circ} \mathrm{C}\end{array}$ & 36.3 & 34.6 \\
\hline & $\begin{array}{l}\text { Spray drying } \\
\text { temp. }=170^{\circ} \mathrm{C}\end{array}$ & 36.0 & 33.9 \\
\hline \multirow{2}{*}{$\begin{array}{l}\text { Milling time } \\
=330 \mathrm{~min} \text {. }\end{array}$} & $\begin{array}{l}\text { Spray drying } \\
\text { temp. }=120^{\circ} \mathrm{C}\end{array}$ & 35.3 & 34. 9 \\
\hline & $\begin{array}{l}\text { Spray drying } \\
\text { temp. }=170^{\circ} \mathrm{C}\end{array}$ & 34.9 & 34.3 \\
\hline
\end{tabular}




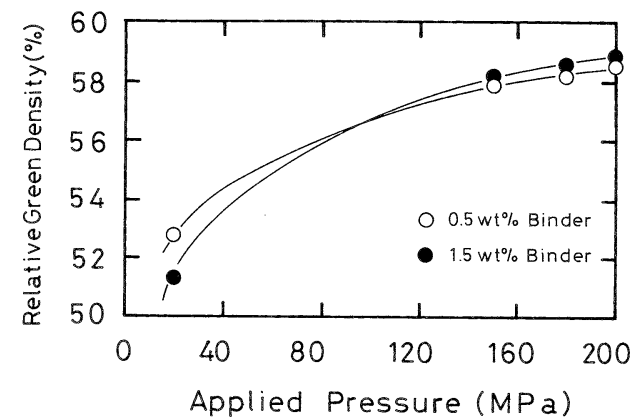

Fig. 8. The relation between relative green density and applied pressure.

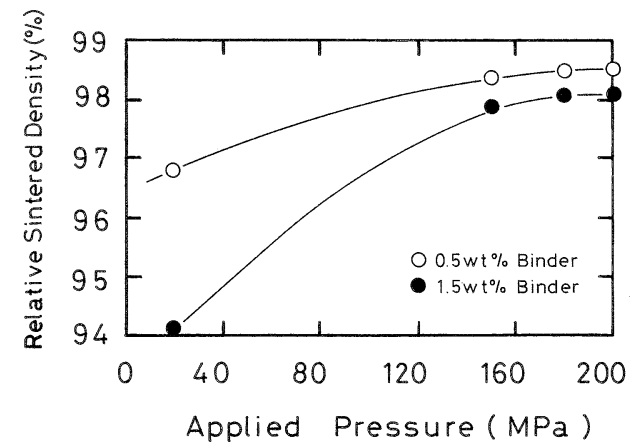

Fig. 9. The relation between relative sintered density and applied pressure.

図 8 は脱脂前の成形体相対密度と成形圧の関係を示した ものであるが，成形圧が高くなるとバインダー配合量の多 い方が密度は同じかやや高くなる傾向を示している。しか し，焼結体の結果は図 9 に示したように成形圧が高くなっ てもバインダー配合量の少ない方が密度は高いままになっ ている.

表 3 は焼結体密度を示したものであるが, バインダー配 合量の少ない方が密度は高い傾向を示し，粉砕時間が30 分の方が330分に比べ密度はわずかであるが高い結果と なった。

表 4 は焼結体の 4 点曲げ強度を示した結果であるが， バインダー配合量の少ない方が多い方より $10 \%$ 程度強度 は高い值を示した。 また粉碎時間においても，粉碎時間が 30 分の方が 330 分に比ベスプレー温度が $120^{\circ} \mathrm{C}$ あいは

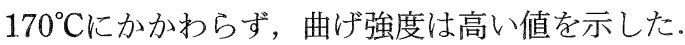

以上より成形体から焼結体までの各段階に扔いて, バイ ンダーの配合量がかなり影響を与えており，バインダーの 配合量が多いと焼結体の特性は下がる傾向にある。バイン ダーの影響については，バインダーの分解とその分解物が セラミックスの焼結に与える影響に着目した実験が行わ れ, バインダーのバーンアウトが不十分であると, 炭素残 留量の多い焼結体ほど収縮率あるいは密度が低くなる ${ }^{9)}$ と の報告があり，バインダーの配合量が多いと残留炭素の影 響が出やすくなっていることも考えられる。しかし本実験 では表 5 に示すように, 脱脂後の炭素量はバインダーの多 少にかかわらずほとんど同じ值を示した。
Table 3. Relative sintered density (\%) of compacts prepared by various conditions.

\begin{tabular}{|c|c|c|c|}
\hline \multirow{2}{*}{\multicolumn{2}{|c|}{ Preparation conditions }} & \multicolumn{2}{|c|}{ Binder content } \\
\hline & & $0.5 \mathrm{wtx}$ & 1. $5 \mathrm{wtx}$ \\
\hline \multirow{2}{*}{$\begin{array}{l}\text { Milling time } \\
=30 \mathrm{~min} \text {. }\end{array}$} & $\begin{array}{l}\text { Spray drying } \\
\text { temp. }=120^{\circ} \mathrm{C}\end{array}$ & 98.7 & 98.3 \\
\hline & $\begin{array}{l}\text { Spray drying } \\
\text { temp. }=170^{\circ} \mathrm{C}\end{array}$ & 98.6 & 98.2 \\
\hline \multirow{2}{*}{$\begin{array}{l}\text { Milling time } \\
=330 \mathrm{~min} .\end{array}$} & $\begin{array}{l}\text { Spray drying } \\
\text { temp. }=120^{\circ} \mathrm{C}\end{array}$ & 98.5 & 98.1 \\
\hline & $\begin{array}{l}\text { Spray drying } \\
\text { temp. }=170^{\circ} \mathrm{C}\end{array}$ & 98.5 & 98.0 \\
\hline
\end{tabular}

Table 4. Four-point bending strength (MPa) of sintered bodies.

\begin{tabular}{|c|c|c|c|}
\hline \multirow{2}{*}{\multicolumn{2}{|c|}{ Preparation conditions }} & \multicolumn{2}{|c|}{ Binder content } \\
\hline & & $0.5 w+x$ & 1. 5 wtx \\
\hline \multirow{2}{*}{$\begin{array}{l}\text { Milling time } \\
=30 \mathrm{~min} \text {. }\end{array}$} & $\begin{array}{l}\text { Spray drying } \\
\text { temp. }=120^{\circ} \mathrm{C}\end{array}$ & 411.6 & 370.4 \\
\hline & $\begin{array}{l}\text { Spray drying } \\
\text { temp. }=170^{\circ} \mathrm{C}\end{array}$ & 407.7 & 363.6 \\
\hline \multirow{2}{*}{$\begin{array}{l}\text { Milling time } \\
=330 \mathrm{~min} \text {. }\end{array}$} & $\begin{array}{l}\text { Spray drying } \\
\text { temp. }=120^{\circ} \mathrm{C}\end{array}$ & 390.0 & 350.8 \\
\hline & $\begin{array}{l}\text { Spray drying } \\
\text { temp. }=170^{\circ} \mathrm{C}\end{array}$ & 358.7 & 335.2 \\
\hline
\end{tabular}

Table 5. Determination of carbon content in compacts before and after dewaxing.

\begin{tabular}{|c|c|c|c|}
\hline \multirow{2}{*}{\multicolumn{2}{|c|}{ Preparation conditions }} & \multicolumn{2}{|c|}{ Binder content } \\
\hline & & $0.5 w t \%$ & $1.5 \mathrm{wtX}$ \\
\hline \multirow{2}{*}{$\begin{array}{l}\text { Milling time } \\
=30 \mathrm{~min} \text {. }\end{array}$} & Before dewaxing & $0.50 \mathrm{wty}$ as carbon & 1. 10 wt $\%$ as carbon \\
\hline & After dewaxing & 0.04 wty as carbon & 0.04 tx as carbon \\
\hline \multirow{2}{*}{$\begin{array}{l}\text { Milling time } \\
=330 \mathrm{~min} \text {. }\end{array}$} & Before dewaxing & $0.50 \mathrm{wt} x$ as carbon & 1. 27utX as carbon \\
\hline & After dewaxing & $0.05 \mathrm{wt} x$ as carbon & $0.04 \mathrm{wt} x$ as carbon \\
\hline
\end{tabular}

粉砝処理時間が 30 分の方が 330 分より焼結体の強度が高 い結果を示したが，混合時間が長くなることにより不純物 混入や，ミルの摩耗等の要因が考光られるが明らかではな い、しかし粉研混合に扔いては適度な混合時間を設定する 必要がある。

\section{4. 結 言}

アルミナの原料調製実験において, バインダーの配合量 を変えたボールミルによる原料調製実験及び原料調製条件 (バインダー配合量, 粉砕時間, 顆粒製造時のスプレー温 度）を変えた媒体かくはんミルによる原料調製実験から顆 粒の特性, 成形性, 焼結体特性について検討を行い以下の 結果を得た.

（1）脱脂前の成形体密度はバインダーの配合量の多い 方が高い值を示し，脱脂後の成形体密度はバインダーの多 
い方が低い值を示した。

（2）焼結体の特性はバインダーの配合が多いと少ない ものより密度, 曲げ強度共に低い值を示した。

（3）以上の結果，成形操作に支障のない限りバイン ダーの配合ができるだけ少ない条件で，原料の調製をする 必要のあることが分かった。

謝辞 本研究は, 日本自転車振興会からの競輪収益の一部 である機械振興資金の補助を受けて実施したものです。

\section{文献}

1）奥田 博, 椿 淳一郎, 杉浦勇夫, 堀田 禎, 佐久間加拈 り，日本セラミックス協会'89年会講演予稿集 (1989) p. 444 .

2）矢吹達美，吉松英之，光石一太，川崎仁士，窐協，95,
1115-18 (1987).

3) C. E. Scott and H. J. Gilbertson, Am. Ceram. Soc. Bull., 61, 579-81 (1982).

4) J. A. Brewer, R. H. Moqre and J. S. Reed, Am. Ceram. Soc. Bull., 60, 212-20 (1982).

5) C. W. Nies and G. L. Messing, "Forming of Ceramics, Vol. 19”, Ed. by J. A. Mangels and G. L. Messing, Am. Ceram. Soc. (1984) pp. 58-66.

6) C. W. Nies and G. L. Messing, J. Am. Ceram. Soc., 67, 30104 (1984).

7) S. Inada, T. Kimura and T. Yamaguchi, Ceram. Int'l, 16, 369-73 (1990).

8) R. G. Frey and J. W. Halloran, J. Am. Ceram. Soc., 67, 199203 (1984)

9）大塚寛治，宇佐美保，関端正雄，喣協，89, 309-18 (1981). 